\title{
Removal of Pharmaceutical Products in a Constructed Wetland
}

\author{
Nihan Özengin, Ayse Elmaci * \\ Department of Environmental Engineering, Gorukle Campus, Faculty of Engineering, Uludag University, 16059, Bursa, \\ Turkey \\ ${ }^{*}$ Corresponding author: Ayse Elmaci, Department of Environmental Engineering, Faculty of Engineering, Uludag University, Gorukle Campus, 16059, \\ Bursa, Turkey. Tel: +90-2242942107, Fax: +90-2242942635, E-mail: aelmaci@uludag.edu.tr
}

Received: April 29, 2015; Revised: February 20, 2016; Accepted: April 20, 2016

Background: There is growing interest in the natural and constructed wetlands for wastewater treatment. While nutrient removal in wetlands has been extensively investigated, information regarding the degradation of the pharmaceuticals and personal care products (PPCPs) has only recently been emerging. PPCPs are widely distributed in urban wastewaters and can be removed to some extent by the constructed wetlands. The medium-term (3-5 years) behavior of these systems regarding PPCP removal is still unknown.

Objectives: The efficiency of a Leca-based laboratory-scale constructed wetland planted with Phragmites australis (Cav.) Trin. Ex. Steudel in treating an aqueous solution of the pharmaceuticals, namely, carbamazepine, ibuprofen, and sulfadiazine, was to investigate.

Materials and Methods: The two pilot-scale constructed wetlands (CW) were operated in parallel; one as an experimental unit (a planted reactor with $P$. australis) and the other as a control (an unplanted reactor with Leca). Pretreatment and analyses of the carbamazepine, ibuprofen, sulfadiazine, and tissue samples (Leca, P. australis body and P.australis leaf) were conducted using HPLC.

Results: The carbamazepine, ibuprofen, and sulfadiazine removal efficiencies for the planted and unplanted reactors were $89.23 \%$ and $95.94 \%, 89.50 \%$ and $94.73 \%$, and $67.20 \%$ and $93.68 \%$, respectively. The Leca bed permitted an efficient removal. Leca has a high sorption capacity for these pharmaceuticals, with removal efficiencies of $93.68-95.94 \%$ in the unplanted reactors.

Conclusions: Sorption processes might be of a major importance in achieving efficient treatment of wastewater, particularly in the removal of organic material that are resistant to biodegradation, in which case the materials composing the support matrix may play an important role. The results obtained in the present study indicate that a constructed wetland with Leca as a substrate and planted with $P$. australis is effective in the treatment of wastewater contaminated with carbamazepine, ibuprofen, and sulfadiazine.

Keywords: Carbamazepine; Constructed Wetland; Ibuprofen Leca; Phragmites australis; Sulfadiazine

\section{Background}

As emerging contaminants, pharmaceuticals and personal care products (PPCPs) are of increasing environmental concern because of their widespread release into the aquatic environments, their persistence, and increasing evidence of their ecotoxicological effects (1-4). Variable concentrations of these compounds have been detected in the surface, ground, and coastal waters into which treated sewage effluents are drained (5-7). Predictive models that estimate PPCPs persistence as a function of the compound's physical and chemical properties have been developed with varying degrees of success for specific water treatment technologies (8-10). Unfortunately, up to now not a single approach has been emerged that could accurately predict PPCP removal during wastewater treatment over a wide range of treatment technologies, water quality condition, and PPCP compounds as well as classes. One of the most highly researched PPCPs is ibuprofen, an over-thecounter anti-inflammatory drug. Sixty-five reports have been presented by the conventional treatment facilities for removing the influent and effluent concentrations of the ibuprofen reporting roughly $70 \%$ efficiencies greater than $1^{-\log 10}$ for removal of the treated wastewaters (2).

Carbamazepine at a concentration of $\mu \mathrm{g} . \mathrm{L}^{-1}$ levels has been measured by many researchers. Working on surface water samples collected in Berlin, concentrations of the carbamazepine at an amount of $1.075 \mu \mathrm{g} . \mathrm{L}^{-1}$ was 
measured (11). The highest reported concentration of carbamazepine in the municipal wastewater was $56 \mu \mathrm{g} . \mathrm{L}^{-1}$ by Mersmann et al. (12).

Sulfadiazine belongs to one of the largest classes of the antibiotics applied in Europe in the animal husbandry. It appears to be quickly transported to the surface water, whereas the transport to the highly sorptive substances appears to be much slower, with concentrations measured in drainage outfalls many months after application (13).

Constructed wetlands are land-based wastewater treatment systems which are consisted of the shallow ponds, beds, or trenches that contain floating or emergentrooted wetland vegetation (14). In subsurface-horizontalflow constructed wetlands (SSFs), wastewater infiltrates through vegetated gravel beds confined by a liner. The wastewater treatment relies on biological, chemical, and physical processes occurring in a natural environment. The potential of SSFs to remove contaminants from urban wastewater has attracted increasing interest over the past decade, particularly for treating wastewater from small communities (15-20).

Phragmites australis (Cav.) Trin. Ex. Steudel, also known as the common reed, is a perennial wetland grass that can grow to 15 feet in height. The invasive variety of phragmites creates tall, dense stands that degrade wetlands and coastal areas by crowding out native plants and animals, blocking shoreline views, and reducing access for swimming, fishing, and hunting. The dry plant material of this variety can also be a fire hazard. It spreads rapidly because of its vigorous rhizomes (horizontal roots that produce new shoots) and can grow more than six feet per year $(21,22)$.

Optimization of a constructed wetland for removal of particular pollutants could be achieved by careful selection of its components, such as the plant species used, and the materials that compose the support matrix. A suitable choice of the latter is especially important for the removal of non-biodegradable compounds (including phenolic compounds, pharmaceuticals, and pesticides) from wastewater, for which sorption processes can play a major role (23-26). In the previous studies, lightweight expanded clay aggregate (Leca) materials have been shown to be suitable for the development of the plants and microorganisms in the constructed wetlands, as well as exhibiting a high capacity for adsorbing many types of the organic molecules (27-33).

Limited information exists about the removal of pharmaceuticals from wastewater in engineered natural systems such as constructed wetlands. The studies conducted to date have pertained primarily to herbicides, pesticides (34-36), and surfactants $(37,38)$. Only a few studies have focused on pharmaceutical removal from wastewater in constructed wetlands $(18,39,40)$.

\section{Objectives}

The study described herein is one of only a few that have investigated the removal of pharmaceuticals from a synthetic domestic wastewater using a laboratoryscale pilot subsurface-flow constructed wetland. In this study, the efficiency of a Leca-based laboratoryscale constructed wetland planted with $P$. australis treating an aqueous solution of pharmaceuticals, namely, carbamazepine, ibuprofen, and sulfadiazine, was evaluated. These pharmaceuticals were chosen on the basis of their high production volume and widespread use. Carbamazepine is the most commonly used drug treatment for epilepsy worldwide. Ibuprofen is the main component of drugs for pain relief, fever, and rheumatic symptoms. Sulfadiazine is an antibacterial drug that is widely used in the veterinary medicine, especially for poultry and fish. In this study, an assessment was carried out on the suitability and performance of a Leca-based laboratory-scale constructed wetland planted with $P$. australis treatment of the wastewater contaminated with these three pharmaceuticals.

\section{Materials and Methods}

\subsection{Reagents and Materials}

Carbamazepine, ibuprofen, and sulfadiazine were purchased from Sigma-Aldrich (Steinheim, Germany). Gravel (grain sizes of 10-15 mm) and Leca (granulometric grades $2 / 4$ and $3 / 8$ ), which were used for the support matrix of the constructed wetland, were supplied by a landscaping firm in Turkey. Prior to use, the gravel and Leca were washed several times with water to remove fine particles and suspended solids.

\subsection{Experimental Set-up and Operating Conditions of Constructed Wetland}

The constructed wetland units were operated in a subsurface-flow mode, in which all influent wastewater was forced to flow through the constructed wetland beds, and no wastewater flowed above the constructed wetland beds. Two pilot-scale subsurface-flow constructed wetland units were constructed from stainless steel, each with dimensions of $0.2 \times 2.45 \times 0.45 \mathrm{~m}$ (width $\times$ length $\times$ depth). A layer of Leca $27 \mathrm{~cm}$ thick was used as the support medium in these units. To facilitate distribution, gravel was used in the influent and effluent zones. These two pilot-scale constructed wetlands were operated in parallel, one as an experi- 
mental unit (a planted reactor with $P$. australis) and the other as a control (an unplanted reactor with Leca). $P$. australis was planted at a density of $4 \mathrm{~m}^{-2}$. Wastewater was fed continuously to the constructed wetlands units to acclimatize the soil microbes and support growth of the cattail plants. All physical, chemical, and biological parameters of the wastewater were analyzed according to the standard methods (41).

\subsection{Support Media (Lightweight Expanded Clay Aggregate, Leca)}

Natural lightweight aggregates are industrial raw materials, usually formed as the product of volcanic porous and large mass distributions. Industrially produced synthetic aggregates include a wide variety of products, generally known by their trade names.

The sintering process occurs rapidly. The specific volume increases at the temperatures between $1100^{\circ} \mathrm{C}$ and $1300^{\circ} \mathrm{C}$ for clay and shale, which are generally called swell able clays. Raw materials for widely used expanded clays include early sintered clay, sandy clay, and shale. The outer surfaces of sintered porous ceramic products are slightly hard and have a pyroclastic structure that forms a shell. This lightweight aggregate material formation is used in the construction industry in lightweight structural elements (42).

\subsection{Operation of the System and Sample Collection}

All systems were operated in a continuous mode. The hydraulic retention time (HRT) of the system was 3 days. This experimental stage was carried out when the reeds were quite well developed. Twenty liters of the synthetic wastewater were spiked daily with each pharmaceutical compound to obtain preselected con-

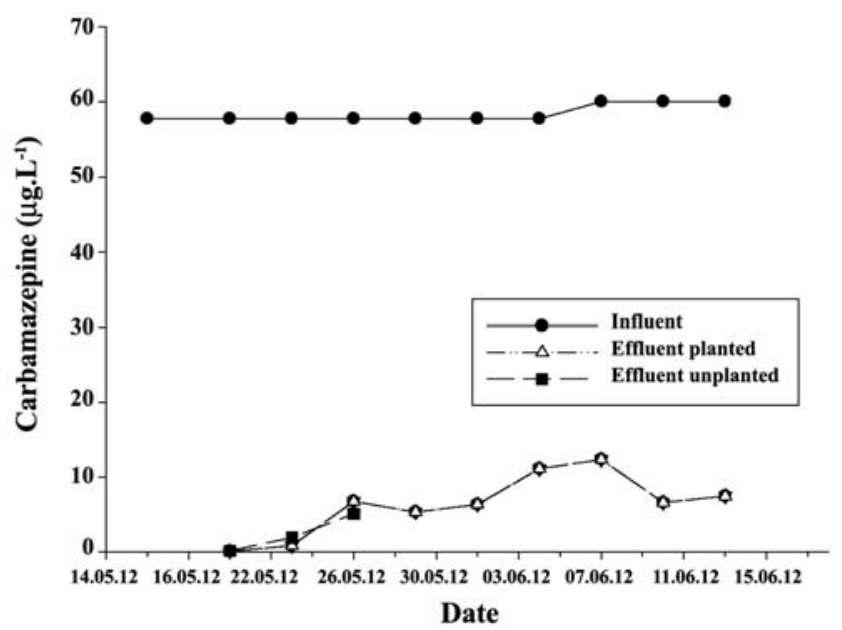

Figure 1. Concentrations of carbamazepine in the influent and effluent of the planted and unplanted reactors centrations of the carbamazepine, ibuprofen, and sulfadiazine. Because there hasn't been a study related to the monitoring pharmaceuticals in the inland waters in Turkey, the influent concentrations of the pharmaceutical compound were set on the basis of the monitoring studies reported in the literature. At the end of the HRT, influent and effluent composite samples were collected. In the planted reactor, the longer-term monitoring was conducted than in the control reactor. Samples were collected in one-liter amber glass bottles and kept refrigerated during transport to the laboratory, where they were stored at $4^{\circ} \mathrm{C}$ until analysis.

\subsection{Analysis of Pharmaceuticals and Tissues}

Pretreatment and analyses of the carbamazepine, ibuprofen, sulfadiazine, and tissue samples (Leca, $P$. australis body and $P$. australis leaf) were conducted in an accredited laboratory in Spain (Ecosur Laboratories) using a dual-pump HPLC equipped with a UV diode array detector.

\section{Results}

\subsection{Carbamazepine Assays}

The average carbamazepine concentration in the subsurface-flow wetland system was $58.43 \mu \mathrm{g} . \mathrm{L}^{-1}$ in the influent, $6.29 \mu \mathrm{g} . \mathrm{L}^{-1}$ in the planted reactor, and $2.37 \mu \mathrm{g} . \mathrm{L}^{-1}$ in the unplanted reactor (Figure 1). The carbamazepine removal efficiencies for the planted and the unplanted reactors were $89.23 \%$ and $95.94 \%$, respectively.

\subsection{Ibuprofen Assays}

Figure 2 shows the ibuprofen concentrations in the

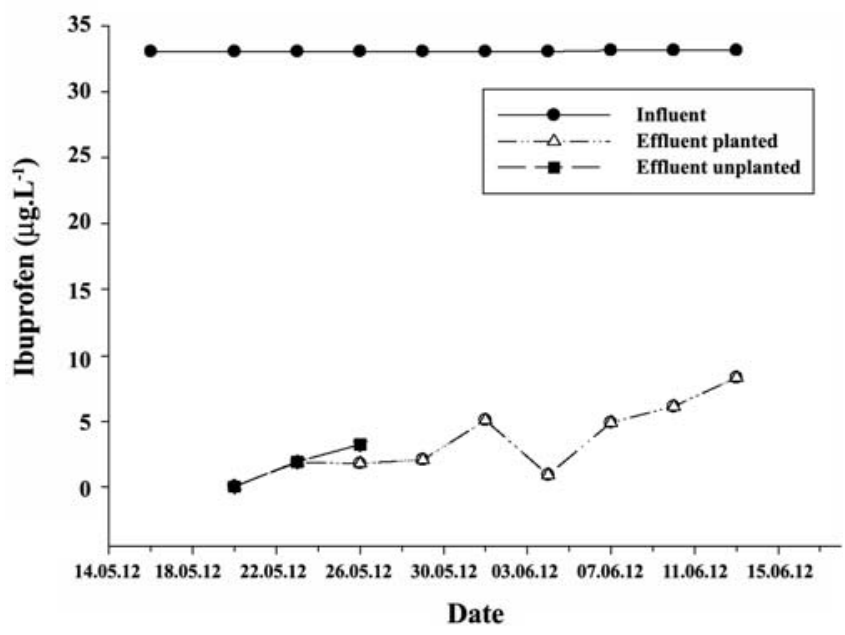

Figure 2. Concentrations of ibuprofen in the influent and effluent of the planted and unplanted reactors 
influent and effluent of the planted and the unplanted reactors. The average ibuprofen concentrations in the subsurface-flow wetland system were $33.07 \mu \mathrm{g} . \mathrm{L}^{-1}$ in the influent, $3.47 \mu \mathrm{g} . \mathrm{L}^{-1}$ in the planted reactor, and $1.74 \mu \mathrm{g} . \mathrm{L}^{-1}$ in the unplanted reactor. The ibuprofen removal efficiencies for the planted and unplanted reactors were $89.50 \%$ and $94.73 \%$, respectively.

\subsection{Sulfadiazine Assays}

The average sulfadiazine concentrations in the subsurface-flow wetland system were $33.39 \mu \mathrm{g} . \mathrm{L}^{-1}$ in the influent, $10.95 \mu \mathrm{g} . \mathrm{L}^{-1}$ in the planted reactor, and 2.11 $\mu \mathrm{g} . \mathrm{L}^{-1}$ in the unplanted reactor (Figure 3 ). The sulfadiazine removal efficiencies for the planted and unplanted reactors were $67.20 \%$ and $93.68 \%$, respectively. The removal efficiency was higher in the unplanted reactor than in the planted reactor.

\subsection{Isotherm Studies}

Two models (the Langmuir and Freundlich models) were used to model the pharmaceutical adsorption of the Leca. These models are useful in full-scale applications.

Original form

Linearized form

1. Langmuir model

$q=\frac{q_{m} \cdot K_{L} \cdot C}{1+K_{L} \cdot C}$ $\frac{C}{q}=\frac{1}{K_{L} q_{m}}+\frac{1}{q_{m}} \cdot C$

2. Freundlich model

$q=K_{F} \cdot C^{1 / n}$

$$
\log q=\log K_{F}+1 / n \cdot \log C
$$

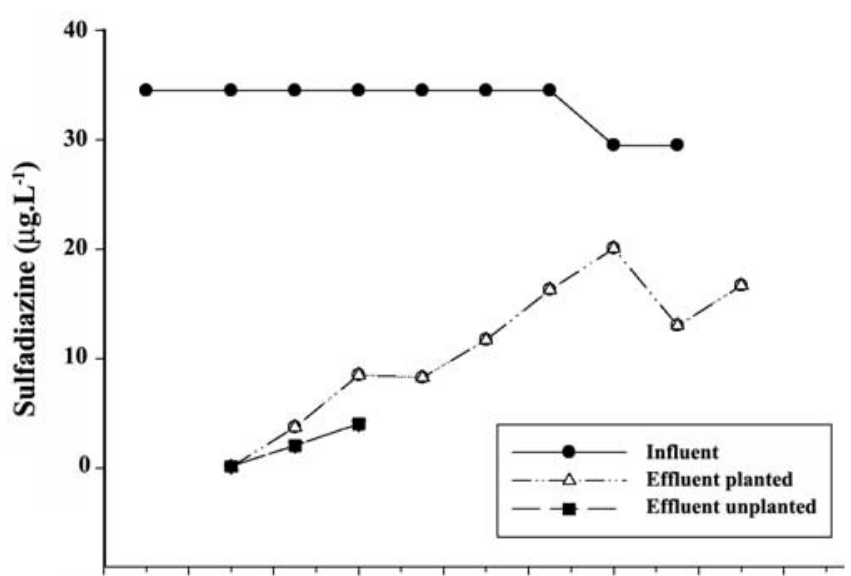

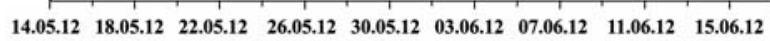

Date

Figure 3. Concentrations of sulfadiazine in the influent and effluent of the planted and unplanted reactors
Table 1. The concentration of the carbamazepine, ibuprofen, and sulfadiazine in the Leca, body, and leaves of the P. australis

\begin{tabular}{lcccc}
\hline The analysis section & $\begin{array}{c}\text { Influent con- } \\
\text { centration }\end{array}$ & $\begin{array}{c}\boldsymbol{P} \text {. aus- } \\
\text { tralis body }\end{array}$ & $\begin{array}{c}\boldsymbol{P} \text {. australis } \\
\text { leaf }\end{array}$ \\
$\begin{array}{l}\text { Pharmaceutical } \\
\text { products }\end{array}$ & & & & \\
\hline Carbamazepine $\mu \mathrm{g} \cdot \mathrm{L}^{-1}$ & 58.43 & 46.58 & 43.75 & 154.55 \\
lbuprofen $\mu \mathrm{g} \cdot \mathrm{L}^{-1}$ & 33.07 & $<5$ & $<5$ & $<5$ \\
Sulfadiazine $\mu \mathrm{g} \cdot \mathrm{L}^{-1}$ & 33.39 & $<5$ & $<5$ & $<5$ \\
& & & & \\
\hline
\end{tabular}

Where: Q: Pollutant quantity adsorbed per specific amount of adsorbent; C: Equilibrium concentration; $\mathrm{q}_{\mathrm{m}}$ : Pollutant quantity required to form a monolayer; $\mathrm{K}_{\mathrm{L}}$ : Langmuir equilibrium constant; $\left(\mathrm{K}_{\mathrm{F}}\right)$, and $(1 / \mathrm{n})$ are indicative isotherm parameters of sorption capacity and intensity, respectively $(43,44)$.

Figures 4-6 show the adsorption of pharmaceuticals. The values of the Freundlich and Langmuir constants are presented in Table 1.

\section{Discussion}

\subsection{Carbamazepine Assays}

Carbamazepine is not efficiently removed from wastewater in any treatment plant (45). Carbamazepine is one of the most durable pharmaceutical products in surface water (46). Plants have an active role in the removal of these compounds through direct uptake. It is widely accepted that organic compounds with $0.5<\log$ Kow $<3$ can pass through cell membranes and enter plants' transpiration streams, thereby easily being taken up by plants. In this study, high removal efficiencies were obtained for both the planted and unplanted reactors. It is thought that removal of carbamazepine $(\log \mathrm{Kow}=2.45)$ from the used subsurface-flow system to have been caused by plant transpiration system and solid-phase biological sorption. As Table 2 is showing, the results obtained for carbamazepine, ibuprofen, and sulfadiazine concentration in the Leca, body, and the leaves of P. australis support this view. Carbamazepine was found to be adsorbed within Leca structure and in the body and leaves of $P$. australis, whereas ibuprofen and sulfadiazine were not. The carbamazepine concentrations in the leaves of the P. australis in Leca, and in the body of the $P$. australis were $154.55 \mu \mathrm{g} . \mathrm{L}^{-1}, 46.58 \mu \mathrm{g} . \mathrm{L}^{-1}$, and $43.75 \mu \mathrm{g} . \mathrm{L}^{-1}$, respectively. Carbamazepine was adsorbed by the leaves of the $P$. australis, the Leca, and the body of the $P$. australis plants (in that order, from highest to the lowest adsorption). For carba- 
A

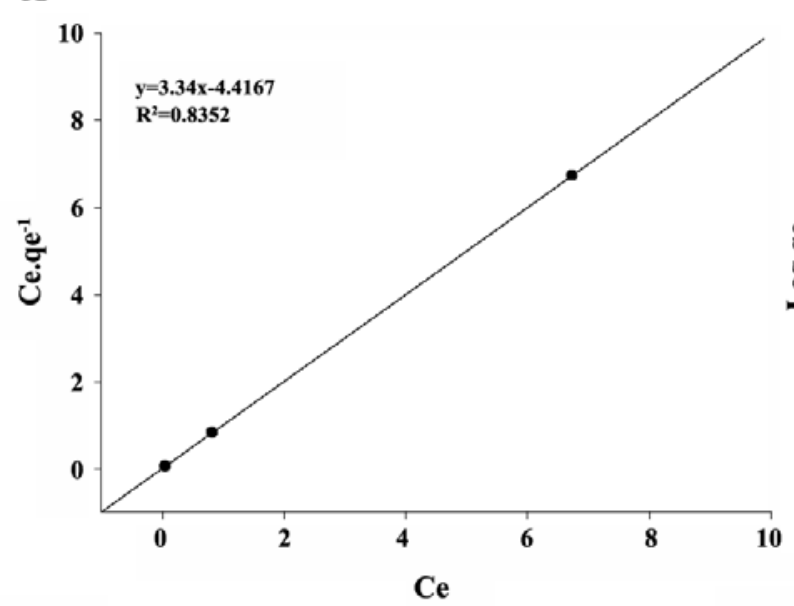

B

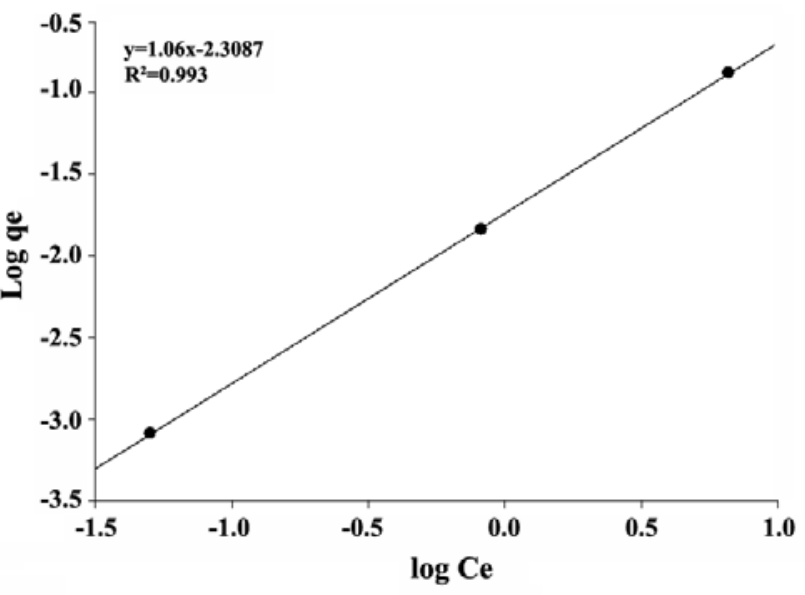

Figure 4. Carbamazepine adsorption A: Langmuir B: Freundlich. qe: Pollutant quantity adsorbed per specific amount of adsorbent; Ce: Equilibrium concentration

A

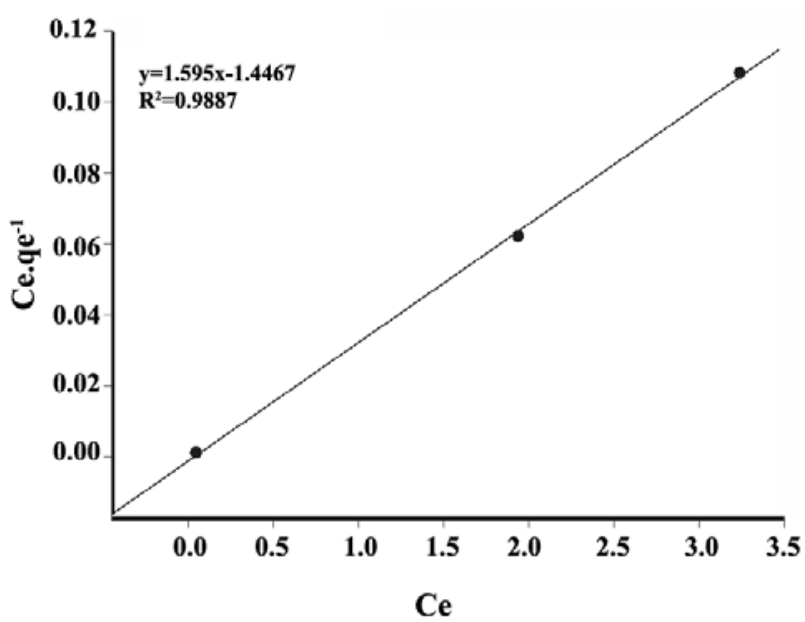

B

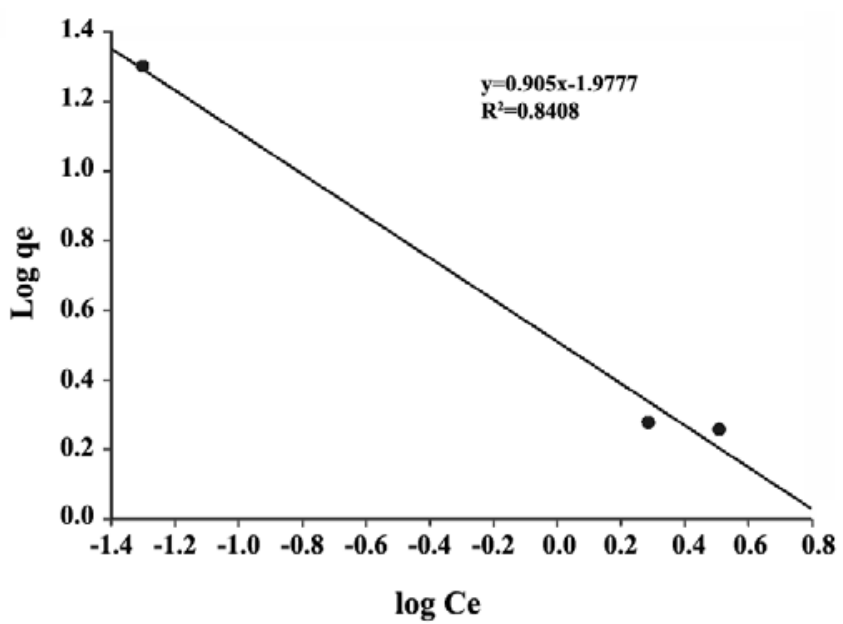

Figure 5. Ibuprofen adsorption A: Langmuir B: Freundlich. qe: Pollutant quantity adsorbed per specific amount of adsorbent; Ce: Equilibrium concentration

mazepine, sorption of the dissolved organic contaminant in that organic matter and on the biofilm coating the Leca bed as well as $P$. australis could be a significant mechanism for their removal.

\subsection{Ibuprofen Assays}

The removal efficiency of the ibuprofen in the treatment plants can be more than $90 \%$, most likely due to the low hydrophobicity of the ibuprofen $(\operatorname{logKow}<3)(47)$. The biological transformation of ibuprofen is the main removal mechanism. However, the removal efficiencies in some wastewater treatment plants are reported to be in the order of $30 \%$ (48). Consistent with the findings reported in the literature, higher removal efficiencies were achieved in this study in both the planted and unplanted reactors, as shown in Figure 2, indicating the concentrations of ibuprofen in the influent and effluent of the planted and unplanted reactors. The fact that ibuprofen did not accumulate in the Leca and $P$. australis, as shown in Table 2, suggests that other mechanisms such as biodegradation play a role in their removal. The ibuprofen concentrations in the leaves of the P. australis in Leca, and in the body of the $P$. australis were $<5 \mu$ g. $\mathrm{L}^{-1}$ in all sample types.

\subsection{Sulfadiazine Assays}

It has been previously reported that sorption, abiot- 
A

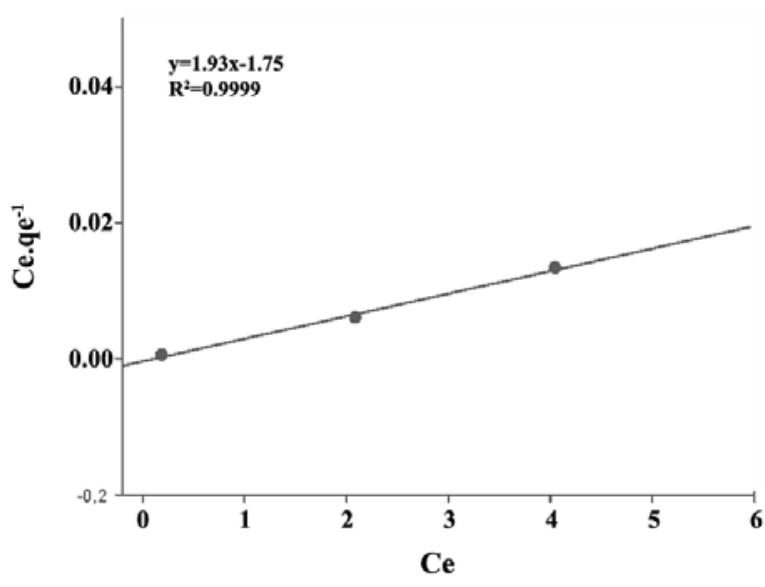

B

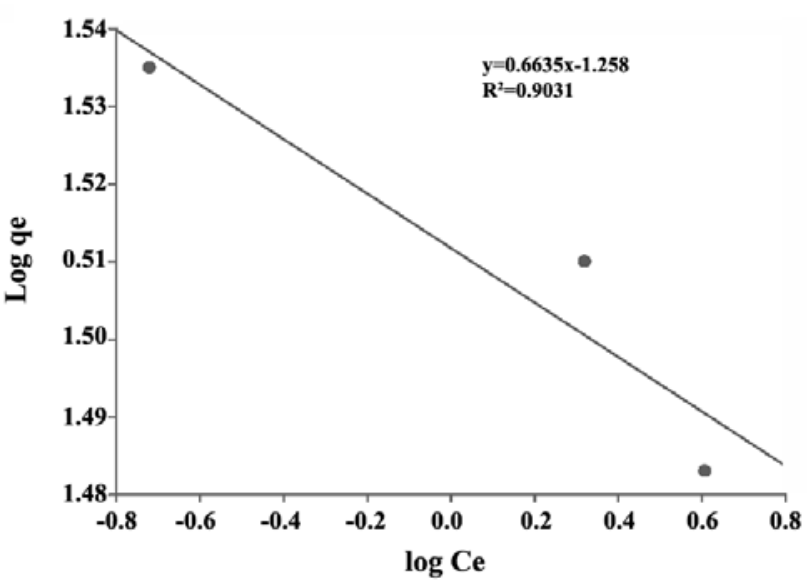

Figure 6. Sulfadiazine adsorption A: Langmuir B: Freundlich

ic transformation, and biotic transformation are the major processes that antibiotics undergo in the natural and engineered aquatic environments (49). Hydrolysis is an important degradation pathway for organic pollutants in aquatic environments (50). In this study, the removal of antibiotics was attributed to their biodegradation in water. It was shown that an unplanted system is more directly insulated and highly populated by microscopic algae, achieved significantly better removal than a planted system (51). It was found that sulfadiazine was removed at lower rates in planted systems (34). The sulfadiazine concentrations in the leaves of the $P$. australis in Leca, and in the body of the P. australis were $<5 \mu \mathrm{g}$. $\mathrm{L}^{-1}$ in all sample types (Table 2). The higher degree of removal achieved in this study in the control reactor indicates that the presence of plants is not important in the removal of sulfadiazine.

\subsection{Isotherm Studies}

The adsorption of pharmaceuticals is better explained by Freundlich isotherm. In carbamazepine and sulfadiazine removal, the system shows compliance with the Freundlich isotherm model $\left(\mathrm{R}^{2}\right.$ values of
0.993 and 0.9031 , respectively). It is dependent on each of these drugs in the presence of a medicament for being adsorbed by the active sites on the surface that are distributed across a heterogeneous show that task. For the adsorption of sulfadiazine, the values for in see Table 1 were found to be greater than 1, which indicates that sulfadiazine is adsorbed better than the other studied pharmaceutical products. When the correlation coefficients $\left(\mathrm{R}^{2}\right)$ of the model graphics are considered, a higher rate of carbamazepine was found to be in agreement with the Freund lich isotherm model. The Langmuir isotherm model did not adequately describe the removal of ibuprofen in the control tank. This degree of adsorption of ibuprofen indicates a monolayer adsorption $\left(\mathrm{R}^{2}=9887\right)$.

\section{Conclusions}

According to the literature, carbamazepine, ibuprofen, and sulfadiazine are the most common and the most used pharmaceutical products found in domestic wastewater, surface, and underground water $(52,53)$. In this study, the treatability of a laboratory-scale constructed wetland system used for removing pharma-

Table 2. Comparison between Langmuir and Freundlich isotherms models as obtained for the three types of the studied pharmaceuticals

\begin{tabular}{lcccccc}
\hline & \multicolumn{3}{c}{ Congmuir Isotherm } & \multicolumn{2}{c}{ Freundlich Isotherm } \\
$\begin{array}{l}\text { Pharmaceutical } \\
\text { products }\end{array}$ & $\mathbf{Q}^{\mathbf{0}}$ & $\mathbf{b}$ & $\mathbf{R}^{\mathbf{2}}$ & $\mathbf{N}$ & $\mathbf{K F}$ & $\mathbf{R}^{\mathbf{2}}$ \\
\hline Carbamazepine & & & & & & \\
lbuprofen & 0.805 & 0.29 & 0.8352 & 0.943 & 0.459 & 0.993 \\
Sulfadiazine & 0.626 & 1.102 & 0.9887 & 1.104 & 0.457 & 0.8408 \\
& 0.518 & 1.102 & 0.8408 & 1.507 & 0.527 & 0.9031 \\
\hline
\end{tabular}


ceutical products was the subject of examination. The obtained results indicate that carbamazepine is adsorbed into the structure of Leca and the body and leaves of $P$. australis, whereas ibuprofen and sulfadiazine are not. While high removal efficiencies were obtained for both planted and unplanted reactors for carbamazepine and ibuprofen, in sulfadiazine assays, the removal efficiency was better for unplanted reactors compared to the planted reactors.

With respect to sulfadiazine and carbamazepine removal, the system exhibited compliance with the Freund lich isotherm model depending on each of these drugs in the presence of a medicament for the adsorption active sites on the surface that are distributed across a heterogeneous show that task. The Langmuir isotherm model did not adequately describe the removal of ibuprofen in the control tank. This degree of ibuprofen adsorption indicates a monolayer adsorption.

Based on the results obtained in this study, other concentrations and hydraulic retention times for pharmaceutical products should be examined in future studies, and more research is needed to be undertaken on the treatment of wastewater contaminated with the pharmaceutical products using constructed wetlands.

\section{Acknowledgments}

This manuscript was edited by American Journal Experts (AJE). This study is a part of the $\mathrm{PhD}$. thesis of the first author, which was accepted on 19.12.2012 by the Graduate School of Natural and Applied Sciences of Uludag University.

\section{Funding/Support}

This work was supported by grants from the Scientific Research Projects Council of Uludag University (Project number 2010/52), Bursa, Turkey.

\section{References}

1. Cunningham VL, Buzby M, Hutchinson T, Mastroco F, Parke N, Roden N. Effects of human pharmaceuticals on aquatic life: next steps. Environ Technol. 2006;40:3456-3462. DOI: $10.1021 / \mathrm{es} 063017 \mathrm{~b}$

2. Oulton RL, Kohn T, Cwiertny DM. Pharmaceuticals and personal care products in effluent matrices: A survey of transformation and removal during wastewater treatment and implications for wastewater management. J Environ Monit. 2010;12:1956-1978. DOI: 10.1039/C0EM00068J

3. Boxall ABA, Rudd MA, Brooks BW, Caldwell DJ, Choi K. Pharmaceuticals and Personal Care Products in the Environment: What Are the Big Questions? Environ Health Perspect.
2012;120(9):1221-1229. DOI: 10.1289/ehp.1104477

4. Ortiz de García SA, Pinto Pinto G, García-Encina PA, IrustaMata R. Ecotoxicity and environmental risk assessment of pharmaceuticals and personal care products in aquatic environments and wastewater treatment plants. Ecotoxicology 2014;23(8):1517-1533. DOI: 10.1007/s10646-014-1293-8

5. Ternes TA. Occurrence of drugs in german sewage treatment plants and rivers. Water Res. 1998;32:3245-3260. DOI: 10.1016/S00431354(98)00099-2

6. Kolpin DW, Furlong ET, Meyer MT, Thurman EM, Zaugg SD, Barber L, Buxton HT. Pharmaceuticals, hormones, and other organic wastewater contaminants in U.S. Streams, 1999-2000: A national reconnaissance. Environ Sci Technol. 2002;36:12021211. DOI: 10.1021/es011055j

7. Buser HR, Muller DM. Occurrence of the pharmaceutical drug clofibric acid and the herbicide mecoprop in various Swis Lakes and in the North Sea. Environ Sci Technol. 1998;32:188-192. DOI: 10.1021/es9705811

8. Kim SD, Cho J, Kim IS, Vanderford BJ, Snyder SA. Occurrence and removal of pharmaceuticals and endocrine disruptors in South Korean surface, drinking, and waste waters. Water Res. 2007;41:1013-1021. DOI: 10.1016/j.watres.2006.06.034

9. Westerhoff P, Yoon Y, Snyder S, Wert E. Fate of endocrine-disruptor, pharmaceutical, and personal care product chemicals during simulated drinking water treatment processes. Environ Sci Technol. 2005;39:6649-6663. DOI: 10.1021/es0484799

10. Redding AM, Cannon FS, Snyder AS, Vanderford BJ.A QSAR-like analysis of the adsorption of endocrine disrupting compounds, pharmaceuticals, and personal care products on modified activated carbons. Water Res. 2009;43:3849-3861. DOI: 10.1016/j.watres.2009.05.026

11. Heberer T. Occurrence, fate, and removal of pharmaceutical residues in the aquatic environment: a review of recent research data. Toxicol Lett. 2002;31:5-17. DOI: 10.1016/S0378-4274(02)00041-3

12. Mersmann P, Scheytt T, Heberer TH. Column experiments on the transport behavior of pharmaceutically active substances in the saturated zone. Acta Hydrochim Hydrobiol. 2002;30:275-284.

13. Boxall ABA, Kolpin DW, Tolls J. Are VETERINARY MEDICINES Causing Environmental Risks? Environ Sci Technol. 2003;37(15):286A-294A. DOI: 10.1021/es032519b

14. Cole S. The emergence of treatment wetlands. Environ Sci Technol. 1998;32:218A-223A. DOI: 10.1021/es9834733

15. Moore TM, Rodgers Jr JH, Cooper CM, Smith S. Constructed wetlands for mitigation of atrazine-associated agricultural runoff. Environ Pollut. 2000;110:393-399. DOI: 10.1016/S02697491(00)00034-8

16. Schulz R, Peall SKC. Effectiveness of a constructed wetland for retention of nonpoint-source pesticide pollution in the Lourens River Catchment, South Africa. Environ Sci Technol. 2001;35:422-426. DOI: 10.1021/es0001198

17. Halling-Sorensen B, Nors Nielsen S, Lanzky PF, Ingerslev F, Holten Lützheft HC, Jorgensen SE. Occurrence, fate and effects of pharmaceutical substances in the environment- A review. Chemosphere. 1998;36(2):357-393. DOI: 10.1016/S0045-6535(97)00354-8

18. Matamoros V, Garci'a J, Bayona JM. Behavior of selected pharmaceuticals in subsurface flow constructed wetlands: a pilot-scale study. Environ Sci Technol. 2005;39:5449-5454. DOI: $10.1021 / \mathrm{es} 050022 \mathrm{r}$ 
19. Hijosa-Valsero M, Matamoros V, Martín-Villacorta J, Bécares E, Bayona JM. Assessment of full-scale natural systems for the removal of PPCPs from wastewater in small communities. Water Research. 2010;44(5):1429-1439. DOI: 10.1016/j.watres.2009.10.032

20. Haarstad K, Bavor HJ, Mæhlum T. Organic and metallic pollutants in water treatment and natural wetlands: a review. Water Sci Technol. 2012;65(1):76-99. DOI: 10.2166/wst. 2011.83

21. Cronk JK, Fennessy MS, Wetland plants: biology and ecology. Lewis Publishers, Florida, 2001.

22. Naz M. Kampüs atik sularinin yapay sulak alanlarla aritimi. Yüksek Lisans Tezi, Harran Üniversitesi, Fen Bilimleri Enstitüsü, Çevre Mühendisligi Anabilimdali, sanliurfa. 2008 (in Turkish).

23. Reddy KR, DeLaune RD. Biogeochemistry of Wetlands: Science and Applications, Boca Raton, FL: CRC Press, 2008.

24. Imfeld G, Braeckevelt M, Kuschk P, Richnow W. Monitoring and assessing processes of organic chemicals removal in constructed wetlands. Chemosphere. 2009;74:349-362. DOI: 10.1016/j.chemo sphere.2008.09.062

25. Ahmad T, Rafatullah M, Ghazali A, Sulaiman O, Hashim R, Ahmad A. Removal of pesticides from water and wastewater by different adsorbents: a review. J Environ Sci Health C Environ Carcinog Ecotoxicol Rev. 2010;28:231-271. DOI: 10.1080/ 10590501.2010.525782

26. Passeport E, Benoit P, Bergheaud V, Coquet Y, Tournebize J. Selected pesticides adsorption and desorption in substrates from artificial wetland and forest buffer. Environ Toxicol Chem. 2011;30:1669-1676. DOI: 10.1002/etc.554

27. Dordio AV, Teimao J, Ramalho I, Palace Carvalho AJ, Estevao Candeias AJ. Selection of a support matrix for the removal of some phenoxyacetic compounds in constructed wetlands systems. Sci Total Environ. 2007;380:237-246. DOI: 10.1016/j. scitotenv.2007.02.015

28. Dordio AV, Candeias AJE, Pinto AP, da Costa CT, Carvalho AJP. Preliminary media screening for application in the removal of clofibric acid, carbamazepine and ibuprofen by ssf-constructed wetlands. Ecol Eng. 2009;35:290-302. DOI: 10.1016/j.ecoleng.2008.02.014

29. Dordio A, Carvalho AJP, Teixeira DM, Dias CB, Pinto AP. Removal of pharmaceuticals in microcosm constructed wetlands using Typha spp. and LECA. Bioresour Technol. 2010;101:886-892. DOI: 10.1016/j.biortech.2009.09.001

30. Calheiros CSC, Rangel AOSS, Castro PML. Evaluation of different substrates to support the growth of Typha latifolia in constructed wetlands treating tannery wastewater over longterm operation. Bioresour Technol. 2008;99:6866-6877. DOI: 10.1016/j.biortech.2008.01.043

31. Matamoros V, Puigagut J, Garcia J, Bayona JM. Behavior of selected priority organic pollutants in horizontal subsurface flow constructed wetlands: A preliminary screening. Chemosphere 2007;69:1374-1380. DOI: 10.1016/j.chemosphere.2007.05.012

32. Imfeld G, Braeckevelt M, Kuschk P, Richnow HH. Review: monitoring and assessing processes of organic chemicals removal in constructed wetlands. Chemosphere 2009; 74:349362. DOI: 10.1016/j.chemosphere.2008.09.062

33. Du B, Price AE, Scott WC, Kristofco LA, Ramirez AJ, Chambliss CK, Yelderman JC, Brooks BW. Comparison of contaminants of emerging concern removal, discharge, and water quality hazards among centralized and on-site wastewater treatment system effluents receiving common wastewater influent. Sci Total Environ. 2014;466-467:976-984. DOI: 10.1016/j.scitotenv. 2013.07.126

34. Cheng S, Vidakovic-Cifrek Z, Grosse W, Karrenbrock F. Xenobiotics removal from polluted water by a multifunctional constructed wetland. Chemosphere 2002;48:415-418. DOI: 10.1016/S0045-6535(02)00097-8

35. Schulz R, Hahn C, Bennett ER, Dabrowski JM, Thiere G, Peall SKC. Fate and effects of azinphos-methyl in a flow-through wetland in South Africa. Environ Sci Technol. 2003a;37:2139-2144. DOI: 10.1021/es026029f

36. Schulz R, Moore MT, Bennet ER, Farris JL, Smith S, Cooper CM. Methyl-parathion toxicity in vegetated and non vegetated wetland mesocosms. Environ Toxicol. 2003b;22:12621268. DOI: 10.1002/etc.5620220611

37. Belmont MA, Metcalfe CD. Feasibility of using ornamental plants (Zantedeschia aethiopica) in subsurface flow treatment wetlands to remove nitrogen, chemical oxygen demand, and nonylphenol ethoxylate surfactants a laboratory-scale study. Ecol Eng. 2003;21:233-247. DOI: 10.1016/j.ecoleng.2003.10.003

38. Huang Y, Latorre A, Barcelo' D, Garci'a J, Aguirre P, Mujeriego R, Bayona JM. Factors affecting linear alkylbenzene sulfonates removal in subsurface flow constructed wetlands. Environ Sci Technol. 2004;38:2657-2663. DOI: 10. 1021/es034821q

39. Gross B, Montgomery-Brown J, Naumann A, Reinhard M. Occurrence and fate of pharmaceuticals and alkylphenol ethoxylate metabolites in an effluent-dominated riverand wetland. Environ Toxicol Chem. 2004;23:2074-2083. DOI: 10.1897/03606

40. Verlicchi P, Zambello E. How efficient are constructed wetlands in removing pharmaceuticals from untreated and treated urban wastewaters? A review. Sci Total Environ. 2014;470471:1281-1306. DOI : 10.1016/j.scitotenv.2013.10.085

41. AWWA-APHA: Standard Methods for the Examination of Water and Wastewater, 21stEdn., American Public Health Association, Bultimore, USA. Washington D.C. 2005.

42. Gündüz L, Sapci N, Bekar M Genlesmis kilin hafif agrega olarak kullanilabilirligi. Kibited. 2006;1(2):43-49 (in Turkish).

43. Freundlich H. Adsorption in solution. Phys Chem Soc. 1906;40:1361-1368.

44. Langmuir I. The adsorption of gases on plane surfaces of glass, mica, and platinum. J Am Chem Soc. 1918;40:1361-1368.

45. Clara M, Strenna B, Gans O, Martinez E, Kreuzingera N, Kroiss H. Removal of selected pharmaceuticals, fragrances and endocrine disrupting compounds in a membrane bioreactor and conventional wastewater treatment plants. Water Res. 2005;39:4797-4807. DOI: 10.1016/j.watres.2005.09.015

46. Tixier C, Singer HP, Oellers S, Müller SR. Occurrence and fate of carbamazepine, clofibric acid, diclofenac, ibuprofen, ketoprofen, and naproxen in surface waters. Environ Sci Technol. 2003;37(6):1061-1068. DOI: 10.1021/es025834r

47. Nakada N, Tanishima T, Shinohara H, Kiri K, Takada T. Pharmaceutical chemicals and endocrine disrupters in municipal wastewater in Tokyo and their removal during activated sludge treatment. Water Res. 2006;40:3297-3303. DOI: 10.1016/j.watres.2006.06.039 
48. Kabak H: Kullanilan Bazi Tibbi llaçlarin Canli Aktif Çamur Biyokütlesi Tarafindan Adsorplanma Özelliginin Incelenmesi. Doktora Tezi, Çukurova Üniversitesi, Fen Bilimleri Enstitüsü, Çevre Mühendisligi Anabilim Dali, Adana, PhD thesis. 2008, (in Turkish).

49. Xian Q, Hu L, Chen H, Chang Z, Zou H. Removal of nutrients and veterinary antibiotics from swine wastewater by a constructed macrophyte floating bed system. J Environ Manage. 2010;91:2657-2661. DOI: 10.1016/j.jenvman.2010.07.036

50. Reddy KR, D'angelo EM. Biogeochemical indicators to evaluate pollutant removal efficiency in constructed wetlands. Wat Sci Tech. 1997;35(5):1-10.

51. Hijosa-Valsero M, Fink G, Schlüsener MP, Sidrach-Cardona R, Martín-Villacorta J, Ternes T, Bécares E. Removal of antibiotics from urban wastewater by constructed wetland optimization. Chemosphere. 2011;83(5):713-719. DOI: 10.1016/j.chemosphere.2011.02.004

52. Nikolaou A, Meric S, Fatta D. Occurrence patterns of pharmaceuticals in water and wastewater environments. Anal Bioanal Chem. 2007;387:1225-1234. DOI: 10.1007/s00216-006-1035-8

53. Li WC. Occurrence, sources, and fate of pharmaceuticals in aquatic environment and soil. Environ Pollut. 2014;187:193201. DOI: 10.1016/j.envpol.2014.01.015 